N. M. Kononenko, A. M. Sheikhali, M. O. Ostapets, V. S. Loboda

National University of Pharmacy

\title{
The effect of the new combined cream on the protein synthetic activity of cells on the model of the thermal skin damage in rats
}

Aim. To study the mechanisms of the reparative action of a new combined cream on the model of thermal burn injury in rats.

Materials and methods. On the model of thermal burn in rats the reparative properties of the new combined cream under the conditional name "Dermalipoin" containing a-lipoic acid, urea, olive oil, tea tree oil, PEG-400 were studied. To determine the level of the protein synthetic activity of cells (epitheliocytes of the stratified squamous epithelium in the epidermis and cells of the fibroblast cell in the edges of healing of thermal damage) the content of ribonucleoproteins (RNP) in the cytoplasm and deoxyribonucleoproteins (DNP) in the nuclei of the cells was assessed by the cytometric method.

Results and discussion. On the model of thermal burn in rats "Dermalipoin" cream showed a more active effect on reparative processes compared to the reference drugs - methyluracil ointment and "Titriol" gel. It indicates a significant increase in the protein synthetic function of epitheliocytes of the stratified squamous epithelium in the epidermis and cells of the fibroblastic series at the healing edges. The reparative activity of the cream was, first of all, provided by the presence of thiol (sulfhydryl) groups in the molecule of lipoic acid, giving it the properties of an antioxidant. The antioxidant effect of lipoic acid promotes more efficient DNA molecule reparation after damage as a result of the oxidative stress.

Conclusions. "Dermalipoin" cream shows a marked reparative effect due to the increase of the protein synthetic activity and acceleration of reparation of DNA molecules of epithelial cells after damage; as a result, the process of healing burns accelerates.

Key words: burns; cream; $\alpha$-lipoic acid; reparation; ribonucleoproteins; dezoxyribonucleoproteins

Н. М. Кононенко, А. М. Шейхалі, М. О. Остапець, В. С. Лобода

Вплив нового комбінованого крему на білково-синтетичну активність клітин на моделі термічних пошкоджень шкіри у щурів

Мета - дослідження механізмів репаративної дії нового комбінованого крему на моделі термічної опікової травми у щурів.

Матеріали та методи. На моделі термічного опіку у щурів досліджені репаративні властивості нового комбінованого крему, умовно названого «Дермаліпоїн», до складу якого увійшли: $\alpha$-ліпоєва кислота, сечовина, оливкова олія, олія чайного дерева, ПЕГ-400. Для визначення рівня білково-синтетичної активності клітин (епітеліоцитів багатошарового плоского епітелію в зоні епідермізації і клітин фібробластичного ряду в краях загоєння термічного пошкодження) проводили оцінку вмісту рибонуклеопротеїдів у цитоплазмі і дезоксирибонуклеопротеїдів у ядрах клітин методом цитофотометрії.

Результати та їх обговорення. На моделі термічного опіку у щурів крем Дермаліпоїн порівняно з препаратами порівняння - маззю метилурациловою та гелем Тітріол виявив більш активний вплив на репаративні процеси, про що свідчило вірогідне збільшення білково-синтетичної функції епітеліоцитів багатошарового плоского епітелію в зоні епідермізації і клітин фрібробластичного ряду в краях загоєння. Репаративну активність крему, насамперед, забезпечила наявність тіолових (сульфгідрильних) груп у молекулі ліпоєвої кислоти, що надає їй властивості антиоксиданта. Антиоксидантний ефект ліпоєвої кислоти сприяє більш ефективній репарації молекул ДНК після пошкодження в результаті «окисного стресу».

Висновки. Крем Дермаліпоїн чинить виразну репаративну дію за рахунок збільшення білково-синтетичної активності та прискорення репарації молекул ДНК епітеліоцитів після пошкодження, що проявляється прискоренням процесу загоєння опіків.

Ключові слова: опіки; крем; а-ліпоєва кислота; репарація; рибонуклеопротеїди; дезоксирибонуклеопротеїди

\section{Н. Н. Кононенко, А. М. Шейхали, М. А. Остапец, В. С. Лобода}

\section{Влияние нового комбинированного крема на белково-синтетическую активность клеток на модели термических повреждений кожи у крыс}

Цель - исследование механизмов репаративного действия нового комбинированного крема на модели термической ожоговой травмы у крыс.

Материалы и методы. На модели термического ожога у крыс изучены репаративные свойства нового комбинированного крема, условно названного «Дермалипоин», в состав которого вошли: а-липоевая кислота, мочевина, оливкове масло, масло чайного дерева, ПЭГ-400. Для определения уровня белково-синтетической активности клеток (эпителиоцитов многослойного плоского эпителия в зоне эпидермизации и клеток фибробластического ряда в краях заживления термического повреждения) проводили оценку содержания рибонуклеопротеидов в цитоплазме и дезоксирибонуклеопротеидов в ядрах клеток методом цитофотометрии. 
Результаты и их обсуждение. На модели термического ожога у крыс крем Дермалипоин по сравнению с препаратами сравнения мазью метилурациловой и гелем Титриол проявил более активное воздействие на репаративные процессы, о чем свидетельствовало достоверное увеличение белково-синтетической функции эпителиоцитов многослойного плоского эпителия в зоне эпидермизации и клеток фрибробластического ряда в краях заживления. Репаративную активность крема прежде всего обеспечило наличие тиоловых (сульфгидрильных) групп в молекуле липоевой кислоты, что обеспечивает ей свойства антиоксиданта. Антиоксидантный эфффект липоевой кислоты способствует более эффективной репарации молекул ДНК после повреждения в результате «окислительного стресса».

Выводы. Крем Дермалипоин проявляет выраженное репаративное действие за счет увеличения белковосинтетической активности и ускорения репарации молекул ДНК эпителиоцитов после повреждения, что проявляется ускорением процесса заживления ожогов.

Ключевые слова: ожоги; крем; а-липоевая кислота; заживление; рибонуклеопротеиды; дезоксирибонуклеопротеиды

Treatment of wounds belongs to the oldest medical problems, which do not lose their relevance today, and its importance becomes more and more socioeconomic because of the additional costs for treatment and significant difficulties in rehabilitation of patients. Despite the significant success the number of patients with the wound process does not decrease, moreover, today it is growing. The huge clinical experience gained during the theoretical and practical study of this line of surgery suggests that even the most effective drugs in the process of their application are losing their effectiveness. The study and identification of new aspects of this problem stimulate the search for targeted effects on the wound process.

A modern view of the problem of treating purulentinflammatory phenomena of soft tissues involves a comprehensive effect on all links of the pathological process. Currently, there is work to create the fundamentally new drugs that would significantly improve the effectiveness of the wound treatment and provide prevention of wound complications. The phase of inflammation is of the greatest interest in studying the process of healing wounds and burns since it is largely determines the course and results of the reparative process. Taking into account modern ideas about the role of free radical oxidation in the wound process pathogenesis the use of antioxidant agents to correct the imbalance in the prooxidant-antioxidant system, regulation of the inflammation process and reduction of the damaged structures due to the membrane-stabilizing action at the level of cells and tissues seem natural. Their application significantly reduces the intensity of inflammation, promotes cleansing of the wound and the rapid formation of productive processes [1].

One of the most important tasks of conservative wound healing is the fight with the pathogenic microflora. Microbial contamination can substantially change the course of the wound process. Along with the mechanical damage to tissues the products of the bacterial vital activity can significantly expand the site of alteration and introduce specificity in the pathogenesis of the primary phases of healing. However, formation of the microorganisms' resistance to antimicrobial drugs and the resulting loss of their pharmacological effectiveness lead to the search for new substances and drugs that can actively affect their growth and development [2]. To achieve this goal drugs with a multi-faceted mechanism of action are used. It is the external application of the drug that allows maximizing the concentration of medicinal substances in the site of inflammation and is the safest since it allows you to easily change the dose, if necessary.

Modern requirements to the local wound-healing and antipyretic drugs include the possibility of using the drug in different phases of the wound process, the absence of toxic, allergic and local anesthetic actions, a wide range of the antibacterial activity, the high antimicrobial and anti-inflammatory activity [3]. However, not all drugs presented at the pharmaceutical market of Ukraine meet these requirements. In addition, wound healing drugs for local application should not cause disturbance of the gas exchange in the skin. These disadvantages are due to the use of fatty bases that do not provide sorption of the wound exudate, can oxidize, have a low yield of the active substance, lead to development a "greenhouse" effect. Taking into consideration the facts mentioned above it is expedient to make ointments and creams on the hydrophilic base.

The most effective for the treatment of wounds and dermatitis, including the infected ones, are multicomponent ointments created on the hydrophilic polymeric bases such as "Levomekol", "Levosin", "Miramistin" ointment, "Pantestine-Darnitsa" gel, "Vundehil" ointment and others. Ingredients included in their composition provide a comprehensive effect on the course of the wound process, namely reparative, antimicrobial, anti-inflammatory, dehydrating action [3]. But these drugs have some disadvantages, such as a rather narrow antimicrobial spectrum, and they can cause allergic reactions.

Taking this into account a complex drug containing a mixture of an effective antibacterial agent and a substance that would have the marked antioxidant properties will be interesting for the experimental and clinical study.

At the Department of Commodity Science of the National University of Pharmacy (NUPh) under the supervision of prof. Baranova I. I. a new combined drug in the form of a cream under the conditional name "Dermalipoin" has been developed to treat inflammatory and microbial skin diseases. It contains $\alpha$-lipoic acid, urea, olive oil, tea tree oil, PEG-400. $\alpha$-Lipoic acid is a powerful antioxidant and an effective anti-inflammatory agent, 
when applied locally it possesses the keratolytic, keratoplastic, bacteriostatic and fungistatic action. Olive oil has the anesthetic and anti-inflammatory effect, helps to heal wounds, ulcers and burns. Tea tree oil is an adaptogen. It has a strong bactericidal, anti-inflammatory, antiedema and reparative effect. PEG-400 is a solvent with the pronounced osmotic activity, which causes its wide application in the production of creams for the treatment of infected wounds where it provides the osmotic and dehydration action, which in turn, accelerates the time of the wound healing.

The aim of the work was to study the mechanisms of the reparative action of a new combined cream on the model of thermal burn injury in rats.

\section{Materials and methods}

The studies were conducted on 50 white non-linear, sexually healthy rats weighing 200-250 g. Animals were divided into 5 groups (10 animals in each group): group 1 - intact control; group 2 - control pathology (animals with the natural healing); group 3 - animals received methyluracil ointment manufactured by Farmak (Ukraine) - a reference drug, analog by the pharmacological action and indications; group 4 - animals treated with "Titriol" gel manufactured by OST-Farm LLC (Ukraine) - a reference drug containing tea tree oil; group 5 animals treated with "Dermalipoin" cream.

A day before the simulation of burn, depilation of the skin $\left(4 \times 4 \mathrm{~cm}^{2}\right)$ was performed on the interloopacic area of the animals' back by shaving with a safe blade. Animals under the ketamine $(100 \mathrm{mg} / \mathrm{kg})$ anesthesia were applied a round metallic plate heated to $200{ }^{\circ} \mathrm{C}$ on the shaved area of the skin for 10 seconds. It corresponds to burns of III A-B - III B degree of clinical classification of burns and is characterized by a damage of the entire thickness of the skin with complete death of hair follicles, sweat and sebaceous glands $[4,5]$. For this purpose, a device with a set temperature scale and an electric soldering iron having a nozzle with a metal plate at its end was used. The treatment began immediately after the thermal action and continued once a day, a thin layer was applied on the affected surface.

All interventions and euthanasia of animals were conducted in accordance with the "General ethical principles of animal experimentation" adopted by the First National Congress on Bioethics (Kyiv, 2001) and the Law of Ukraine "On protection from cruelty to animals" No. 3477-IV dated 21.02.2006.

On day 15 the level of the protein synthetic activity of cells (epitheliocytes of the stratified squamous epithelium in the epidermis and fibroblast cells at the edges of healing of the thermal damage) in animals of all experimental groups the content of ribonucleoproteins (RNP) in the cytoplasm and deoxyribonucleoproteins (DNP) in the nuclei of the cells was assessed. By the cytometric method the flow of radiation (in the green part of the spectrum) falling on the object (the object glass) and passing through the object (tissue) on the sections treated with the histochemical methods of Brachet (the solution of crystalline ribonuclease as the control) and FeulgenRossenbeck (the reaction of hydrolysis with $\mathrm{HCl}$ as the control) was measured with the subsequent calculation of the optical density as a decimal logarithm according to the formula:

$$
\mathrm{D}=\lg \left(\frac{\mathrm{F}_{\text {in }}}{\mathrm{F}_{\text {out }}}\right),
$$

where: $\mathrm{D}$ - is the optical density (conventional units); $\mathrm{F}_{\text {in }}$ - is the flow of radiation falling on the object; $\mathrm{F}_{\text {out }}$ is flow of radiation passing through the object; $\mathrm{F}_{\text {in }} / \mathrm{F}_{\text {out }}-$ is the transmittance factor.

RNP in epitheliocytes of the stratified squamous epithelium of the epidermis zone was counted in all layers (basal + parabasal (spiky), medium (intermediate), (granular + brilliant), superficial (horny) and the total value); DNP was determined in epitheliocytes of the basal and parabasal layers in the complex. Histological and histochemical methods were performed according to the formulations contained in the instructions on histological technique and histochemistry $[6,7]$. The research complex was conducted on an Olympus BX-41 microscope using Olympus DP-Soft (Version $3: 1$ ) and Microsoft Excel. The statistical processing of the results obtained was carried out on a Pentium III personal computer using the "Statistica 6" software, as well as Student t-test to compare independent samples at probability level of $\mathrm{p} \leq 0.05[8,9]$.

\section{Results and discussion}

In all experimental groups a similar morphological pattern of healing of ulcer defects by the type of incomplete reparative regeneration with formation of the connective tissue was observed, on day 15 it corresponded to the classification of phases of the wound process according to M. I. Kuzin [10] - transition of the second phase of wound healing (the regeneration phase) to the third phase (the phase of formation and reorganization of the scar and epithelization).

According to the literature data it is known that the mechanism of action of wound-healing drugs consists in their integral effect on the healing of wound lesions (immunostimulation, activation of mitoses, the synthesis of nucleic acids and connective tissue elements, inhibition of lipid peroxidation processes of the membrane structures and other pro-inflammatory factors). The level of the protein synthetic activity was determined by measuring the optical density of RNP in the cytoplasm and DNP in the nuclei of epitheliocytes of the stratified squamous epithelium in the epidermisation zone and cells of the fibroblastic series at the edges of the thermal damage healing. The results are presented in Tab. 1 and 2.

"Dermalipoin" cream showed a more active effect on reparative processes compared to the reference drugs - methyluracil ointment and "Titriol" gel. It indicates a significant increase in the protein synthetic function of epitheliocytes of the stratified squamous epithelium in the epidermis and cells of the fibroblastic series at the healing edges.

The reparative activity of the cream was, first of all, provided by the presence of thiol (sulfhydryl) groups in the molecule of lipoic acid, giving it the properties of an antioxidant. The antioxidant effect of lipoic acid 
Table 1

The optical density of RNP in the cytoplasm of epitheliocytes of the stratified squamous epithelium in the epidermis and cells of the fibroblastic series at the healing edges, conventional units $(\mathrm{M} \pm \mathrm{m})$

\begin{tabular}{|c|c|c|c|c|c|}
\hline \multirow{2}{*}{ Group } & \multicolumn{4}{|c|}{ Layers of the epithelium } & \multirow{2}{*}{$\begin{array}{c}\text { Cells of the } \\
\text { fibroblast series }\end{array}$} \\
\hline & basal + parabasal & medium & superficial & the total value & \\
\hline Intact control & $\begin{array}{c}0.193027 \pm \\
0.014992 \\
\end{array}$ & $\begin{array}{c}0.113774 \pm \\
0.019649 \\
\end{array}$ & $\begin{array}{c}0.112675 \pm \\
0.015566 \\
\end{array}$ & $\begin{array}{c}0.106492 \pm \\
0.010063 \\
\end{array}$ & $\begin{array}{c}0.045035 \pm \\
0.01237 \\
\end{array}$ \\
\hline Control pathology & $\begin{array}{l}0.030174 \pm \\
0.020429^{*}\end{array}$ & $\begin{array}{l}0.025397 \pm \\
0.009429^{*}\end{array}$ & $\begin{array}{l}0.035169 \pm \\
0.010944^{*}\end{array}$ & $\begin{array}{l}0.02358 \pm \\
0.009034^{*}\end{array}$ & $\begin{array}{c}0.003325 \pm \\
0.01647^{*} \\
\end{array}$ \\
\hline Methyluracil ointment & $\begin{array}{l}0.090775 \pm \\
0.01881^{* * * *}\end{array}$ & $\begin{array}{c}0.070343 \pm \\
0.022805^{*} / * * \\
\end{array}$ & $\begin{array}{l}0.088967 \pm \\
0.03026^{*} / * * \\
\end{array}$ & $\begin{array}{c}0.083361 \pm \\
0.014315^{*} / * * \\
\end{array}$ & $\begin{array}{c}0.037282 \pm \\
0.009364^{*} / * * \\
\end{array}$ \\
\hline "Titriol" gel & $\begin{array}{c}0.119201 \pm \\
0.035103^{*} / * * \\
\end{array}$ & $\begin{array}{c}0.081806 \pm \\
0.016364^{*} /^{* * *}\end{array}$ & $\begin{array}{c}0.098823 \pm \\
0.016395^{*} / * *\end{array}$ & $\begin{array}{c}0.109944 \pm \\
\left.0.015962^{*}\right|^{* *} \\
\end{array}$ & $\begin{array}{c}0.052892 \pm \\
0.006829^{*} / * *\end{array}$ \\
\hline "Dermalipoin" cream & $\begin{array}{l}0.172154 \pm \\
0.034711^{* *}\end{array}$ & $\begin{array}{l}0.141931 \pm \\
0.034318^{* * *}\end{array}$ & $\begin{array}{l}0.133001 \pm \\
0.026131^{* * *}\end{array}$ & $\begin{array}{l}0.142362 \pm \\
0.018573^{* *}\end{array}$ & $\begin{array}{c}0.0997 \pm \\
0.015728^{* *}\end{array}$ \\
\hline
\end{tabular}

Notes: ${ }^{*}$ - the differences are statistically significant compared to the values of the intact control group ( $\left.p \leq 0.05\right)$;

** - the differences are statistically significant compared to the values of the control pathology group $(p \leq 0.05)$.

Table 2

The optical density of DNP in the nuclei of epitheliocytes of the stratified squamous epithelium in the epidermis and cells of the fibroblastic series at the healing edges, conventional units $(\mathrm{M} \pm \mathrm{m})$

\begin{tabular}{|l|c|c|}
\hline \multicolumn{1}{|c|}{ Group } & Basal + parabasal layers of the epithelium & Cells of the fibroblast series \\
\hline Intact control & $0.024902 \pm 0.004981$ & $0.0447018 \pm 0.0070152$ \\
\hline Control pathology & $0.001351 \pm 0.004753^{*}$ & $0.019985 \pm 0.009009^{*}$ \\
\hline Methyluracil ointment & $0.016717 \pm 0.005357^{*} / *^{* *}$ & $0.033763 \pm 0.006682^{*} /^{* *}$ \\
\hline "Titriol" gel & $0.019805 \pm 0.005028^{*} / * *$ & $0.032966 \pm 0.005795^{*} /^{* *}$ \\
\hline "Dermalipoin" cream & $0.026836 \pm 0.007445^{* *}$ & $0.0412069 \pm 0.011268^{* *}$ \\
\hline
\end{tabular}

Notes: * - the differences are statistically significant compared to the values of the intact control group ( $p \leq 0.05)$;

** - the differences are statistically significant compared to the values of the control pathology group $(p \leq 0.05)$.

promotes more efficient DNA molecule reparation after damage as a result of the oxidative stress [11].

As for cells of the fibroblastic series they also had the highest protein synthetic activity in the group treated with "Dermalipoin" cream. It is confirmed by the morphological pattern of the defect healing in this group.

\section{CONCLUSIONS}

1. On the model of thermal burn in rats, it was found that when using "Dermalipoin" the optical density of ribonucleoproteins in the cytoplasm and deoxyribonucleoproteins in the nuclei of the epithelial cells of the stratified squamous epithelium in the epidermis and cells of the fibroblastic series at the healing edges increases compared to the control pathology and the groups of the reference drugs $(\mathrm{p} \leq 0.05)$.

2. "Dermalipoin" cream shows a marked reparative effect due to the increase of the protein synthetic activity and acceleration of reparation of DNA molecules of epithelial cells after damage; as a result, the process of healing burns accelerates compared to the control pathology and the reference drugs $(\mathrm{p} \leq 0.5)$.

Conflict of Interests: authors have no conflict of interests to declare.

\section{REFERENCES}

1. Абаев, Ю. К. Справочник хирурга. Раны и раневая инфекция / Ю. К. Абаев. - Ростов н/Д : Феникс, 2006. - 427 с.

2. Гайдуль, К. В. Раневая инфекция: этиология, диагностика и антимикробная терапия : крат. информ. пособ. для практ. врачей / К. В. Гайдуль, А. А. Муконин. - М. : АБОЛмед, 2005. - 32 с.

3. Нагайчук, В. І. Сучасні підходи до надання допомоги хворим з опіками / В. І. Нагайчук // Мистецтво лікування. - 2010. № 5. - C. 24-27.

4. Експериментальне вивчення нових препаратів для місцевого лікування ран : метод. рек. / Л. В. Яковлєва, О. В. Ткачова, Я. О. Бутко, Ю. Б. Лар'яновська. - Х. : НФаУ, 2013. - 52 с.

5. Кушкун, А. А. Руководство по лабораторным методам диагностики / А. А. Кушкун. - М. : ГЭОТАР-Медиа, $2007 .-800$ с.

6. Пирс, Э. Гистохимия теоретическая и прикладная / Э. Пирс. - М., 1962. - 962 с.

7. Соколовский, В. В. Гистохимические исследования в токсикологии / В. В. Соколовский. - Л. : Медицина, $1971 .-176$ с. 
8. Зайцев, В. М. Прикладная медицинская статистика / В. М. Зайцев, В. Г. Лифляндский, В. И. Маринкин. - С.Пб : ФОЛИАНТ, 2003. $-429 \mathrm{c}$.

9. Лапач, С. Н. Статистические методы в медикобиологических исследованиях с использованием Ехсеl / С. Н. Лапач, А. В. Чубенко, П. Н. Бабич. - 2-е изд., перераб. и доп. - К. : МОРИОН, 2001. - 408 с.

10. Кузин, М. И. Раны и раневая инфекция : руководство для врачей / М. И. Кузин, Б. М. Костюченок. - 2-е изд., перераб. и доп. М. : Медицина, 1990. -592 с.

11. The protective effect of a-lipoic acid on mitochondria in the kidney of diabetic rats / L. Wang, C. G. Wu, C. Q. Fang et al. // Int. J. Clin. Exp. Med. - 2013. - Vol. 6, Issue 2. - P. 90-97.

\section{REFERENCES}

1. Abaev, Yu. K. (2006). Spravochnik khirurga. Rany i ranevaia infektciia. Rostov n/D: Feniks, 427.

2. Gaidul, K. V., Mukonin, A. A. (2005). Ranevaia infektciia: etiologiia, diagnostika i antimikrobnaia terapiia. Moscow: ABOLmed, 32.

3. Nahaichuk, V. I. (2010). Mystetstvo likuvannia, 5, 24-27.

4. Yakovlieva, L. V., Tkachova, O. V., Butko, Ya. O., Larianovska, Yu. B. (2013). Eksperymentalne vyvchennia novykh preparativ dlia mistsevoho likuvannia ran. Kharkiv: NUPh, 52.

5. Kushkun, A. A. (2007). Rukovodstvo po laboratornym metodam diagnostiki. Moscow: GEOTAR-Media, 800.

6. Pirs, E. (1962). Gistokhimiia teoreticheskaia i prikladnaia. Moscow, 962.

7. Sokolovskii, V. V. (1971). Gistokhimicheskie issledovaniia v toksikologii. Lviv: Meditcina, 176.

8. Zaitcev, V. M., Lifliandskii, V. G., Marinkin, V. I. (2003). Prikladnaia meditcinskaia statistika. Sankt-Petersburg: FOLIANT, 429.

9. Lapach, S. N., Chubenko, A. V., Babych, P. N. (2001). Statisticheskie metody v medikobiologicheskikh issledovaniiakh s ispolzovaniem Exsel. Kiev, 408 .

10. Kuzin, M. I., Kostiuchenok, B. M. (1990). Rany i ranevaia infektciia. Moscow: Meditcina, 592.

11. Wang, L., Wu, C. G., Fang, C. Q. et al. (2013). The protective effect of a-lipoic acid on mitochondria in the kidney of diabetic rats. Int. J. Clin. Exp. Med., 6, (2), 90-97.

Information about authors:

Kononenko N., Doctor of Medicine (Dr. habil.), professor, head of the Department of Pathological Physiology, National University of Pharmacy.

E-mail: kononenkonn76@gmail.ru

Sheikhali A., postgraduate student of the Department of Pathological Physiology, National University of Pharmacy

Ostapets M., Candidate of Medicine (PhD), teaching assistant of the Department of Pathological Physiology, National University of Pharmacy

Loboda V., Candidate of Physical Education and Sports (PhD), head of the Department of Physical Education and Health, National University of Pharmacy

Відомості про авторів:

Кононенко Н. М., д-р мед. наук, професор, завідувач кафедри патологічної фізіології, Національний фармацевтичний університет. Е-таil: kоnоnеnkonn76@gmail.ru

Шейхалі А. М., аспірант кафедри патологічної фізіології, Національний фармацевтичний університет

Остапець М.О., канд. мед. наук, асистент кафедри патологічної фізіології, Національний фармацевтичний університет

Лобода В.С., канд. наук з фізичного виховання та спорту, завідувач кафедри фізичного виховання та здоров'я, Національний фармацевтичний університет

Сведения об авторах:

Кононенко Н. Н., Д-р мед. наук, профессор, заведующая кафедрой патологической физиологии, Национальный фармацевтический университет.

E-mail: kononenkonn76@gmail.ru

Шейхали А. М., аспирант кафедры патологической физиологии, Национальный фармацевтический университет

Остапец М. А., канд. мед. наук, ассистент кафедры патологической физиологии, Национальный фармацевтический университет

Лобода В.С., канд. наук по физическому воспитанию и спорту, заведующий кафедрой физического воспитания и здоровья, Национальный

фармацевтический университет 